\title{
TEORES DE NITRATO E NITRITO, DETERMINAÇÃO DE PH E ATIVIDADE DE ÁGUA EM LINGUIÇAS DO TIPO FRESCAL ORIUNDAS DO NOROESTE DO RIO GRANDE DO
} SUL.

\author{
(LEVELS OF NITRATE AND NITRITE, DETERMINATION OF pH AND WATER ACTIVITY IN
}

SAUSAGES FRESCAL FROM THE NORTHWEST OF RIO GRANDE DO SUL)

\section{A. S. BOHRZ ${ }^{1}$, J. M. BRUSTOLIN ${ }^{2}$, N. D. CERESER ${ }^{3 *}$, F. R. PINTO ${ }^{3}$}

Sais de cura, como nitrato e nitrito de sódio e de potássio, são largamente utilizados como aditivos alimentares no processamento de produtos cárneos. Além de conservarem a carne contra a deterioração bacteriana, são fixadores de cor e agentes de cura. A aplicação desses sais acima do limite máximo estabelecido pela legislação brasileira (Portaria $n^{\circ}$ 1004/1998-ANVISA), 0,015g/100g e $0,03 \mathrm{~g} / 100 \mathrm{~g}$ do produto, respectivamente para nitrito e nitrato de sódio, pode acarretar sérios riscos à saúde humana, pela possibilidade de manifestações de efeitos tóxicos agudos e crônicos. O objetivo do trabalho foi determinar a quantidade de nitrato e nitrito em linguiças do tipo frescal produzidas em estabelecimentos submetidos aos diferentes níveis de inspeção (Federal e Estadual) ou não inspecionados e comparar os valores encontrados com os preconizados pela legislação brasileira. Para isso, seis amostras de cada grupo foram coletadas no comércio varejista da região Noroeste do Estado do Rio Grande do Sul e analisadas em triplicata. Também foi determinada a atividade de água (Aw) e o $\mathrm{pH}$ de todas as amostras. Dentro o total de amostras os valores variaram entre 5,25 e 6,27 para o $\mathrm{pH}$ e entre 0,849 e 0,890 para Aw. As quantidades de nitrito presentes em $100 \mathrm{~g}$ foram, respectivamente para linguiças frescais produzidas em estabelecimentos de Inspeção Federal, Estadual e sem inspeção, 0,00012g, 0,00016g e 0,00006g. Para nitrato as médias observadas foram $0,0017 \mathrm{~g}, 0,0050 \mathrm{~g}$ e $0,0002 \mathrm{~g}$. Assim, nenhuma das amostras continha quantidades que excediam os limites máximos de tolerância para nitrito e nitrato de sódio para carnes e produtos cárneos, concluindo-se que as amostras analisadas não ofereciam riscos à saúde humana em relação às análises realizadas.

${ }^{1}$ Mestranda, Universidade de Passo Fundo, RS.

${ }^{2}$ Mestranda, Universidade Federal de Santa Maria, RS

${ }^{3}$ Prof $^{\mathrm{a}}$. Dr ${ }^{\mathrm{a}}$. Universidade Federal de Pelotas, RS. natachacereser@yahoo.com.br 